\title{
Counter-Hegemony with No Outlet: A Neo-Gramscian Perspective on the Brexit Vote
}

\author{
Allan Cooper Della iD \\ a PhD Candidate, Area Studies Department, Middle East Technical University, Ankara, Turkey
}

\begin{abstract}
It is tempting when viewing the Brexit referendum and its justifications to lean on identity based analyses for explanations, pointing to a rise in right wing nationalism. However, if we are to look at the economic standing of those who voted no in the Brexit referendum, and moreover, to realize their place in larger flows of neoliberalism, a more complex picture comes into view. Neo-Gramscian theory is uniquely placed on this backdrop in its ability to give us a critical perspective on hegemony, as well as backlash towards it. In the course of this paper, the possibility that Brexit offers us an example of anti-hegemonic backlash against the larger neoliberal project of the EU will be explored. That is to say, in the context of an organic project of neoliberal expansion in which the leftist alternative in the UK has largely come to support further integration into the $\mathrm{EU}$, to what extent can the Brexit vote be seen as counter-hegemony with no outlet?
\end{abstract}

ARTICLE HISTORY

Received: 15.12 .2021

Revised: 05.01 .2022

Accepted: 07.01.2022

\section{KEYWORDS}

Brexit

neoliberalism

neo-Gramscianism

hegemony

\section{Introduction}

Often in academic analyses of Brexit voting patterns, a top-down perspective is used, neglecting the agency of the common people in their voting behavior. On the other hand, even constructivist analyses, which focus on the role of identity in decision making processes, fall short in the amount of attention they pay towards the complexities of international capital and its relation to the dispossessed dispositions seen among many Brexit voters. Therefore, it becomes necessary to combine both a sensitivity for intersubjective construction with an analysis of how that intersubjectivity is part of a larger logic of capitalism. In the Brexit vote, we have a situation in which hegemonic consensus has come into crisis due to economic restructuring, and its legitimacy has therefore been questioned. If we look again from the dual perspectives of the international expansion of capital as well as hegemony, we can begin to re-interpret the backlash seen in the Brexit vote through the lens of counter-hegemony in response to a neoliberal project on the EU level. The purpose of the present study is to reinterpret the Brexit vote through this neo-Gramscian language of hegemony and counter-hegemony. In that sense, the question then becomes to what extent the Brexit vote can be seen to represent counter-hegemonic characteristics in relation to the positionality and choice patterns employed by those who voted against membership in the EU. In the course of this investigation, first, neo-Gramscian perspectives of politics and society will briefly be outlined, then, a brief outline of the UK and the EU in the sense of their incorporation into neoliberal capital will be put forward, as well as the position of left wing politics within this, and then, finally, our attention will be turned to the perspectives of the common people in the UK in terms of their voting behavior 
in the Brexit vote and their positionality in terms of their economic disadvantage in relation to expanding neoliberalism.

\section{A Foundation in a Neo-Gramscian Perspective}

Gramsci saw the state as a social complex well-grounded into civil society, "an entire complex of practical and theoretical activities within which the ruling class not only justifies and maintains its dominance, but manages to win the active consent of those over whom it rules" (Gramsci, 1971, quoted in Robinson, 2005, p. 562). Cox explains the global expansion of hegemony as, "an expression of broadly based consent, manifested in the acceptance of ideas and supported by material resources and institutions, which is initially established by social forces occupying a leading role within a state... then projected outwards on a world scale" (referenced in Bieler and Morton, 2004, p. 87). Cox, as well as Bieler and Morton, focus on a vision of hegemony that is manifested in intersubjective meanings and how it shapes reality. This is a reality that makes room for not only "human action but also the institutional, moral and ideological context that shapes thoughts and actions" (Cox quoted in Bieler and Morton, 2004, p. 87). Therefore, hegemony is more of a consensual order. That is, if hegemony is understood as an "opinion-molding activity," rather than brute force of dominance, then consideration has to turn to how a hegemonic social or world order is based on values and understandings that permeate the nature of that order (Bieler and Morton, 2004, p. 87).

Hegemony is not hegemonic in that it is unchanging, but can be understood in a processual way. In a sense, it is a "hegemonic moment." A "Hegemonic moment" refers to the moment when interests "go beyond the specific confines of an economic group and can and must become the interests of the subordinate groups..." (Gill, 2000, p. 17). Hegemony is instituted in the "contested and shifting set of ideas" through which a dominant group aims to get the consent of a subordinate group: "what is required is the consent of other groups in order to consolidate their power... the union of these social forces that enable hegemony is called the "historic bloc'" (Gibbins, 2020, p. 6). Organic ideas are "organic" in that they "organize human masses, and create the terrain on which men move, acquire consciousness of their position, struggle, etc." (Gramsci, 1971, quoted in Bieler, 2005, p. 518). The conduit between the masses, social forces and ideas is then provided by "organic intellectuals" who represent certain social forces or classes. These intellectuals, "do not simply produce ideas, but they concretize and articulate strategies in complex and often contradictory ways, which is possible because of their class location" (Bieler, 2005, p. 518). The organic intellectuals are then tasked with organizing "the social forces they stem from and to develop a 'hegemonic project', which is able to transcend the particular economic-corporate interests of their social group by binding and cohering diverse aspirations, interests and identities into an historical bloc" (Bieler, 2005, p. 518).

Bieler points to a focus on the level of class in analyses of hegemony which is notable in that it suggests the possibility of the transnationalization of national structures in a similar vein to Cox. He goes on to quote Cox, "it becomes increasingly pertinent to think in terms of a global class structure alongside or superimposed upon national class structures" (Cox, 1981, quoted in Bieler, 2005, p. 516). This naturally takes us to the level that, there exists struggle between national and transnational forces of capital and labor like there also exists that of labor versus capital (at the national level) (Bieler, 2005, p. 516). This idea of levels is pertinent in analysis of the EU. There can be European transnational forces, as well as global forces of capital and labor. Furthermore, there can also be a national level: "national capital and labor may oppose neoliberalism, since they depend on state protectionism against international competition. At the European level, European transnational forces may favor strong internal integration..." (Bieler, 2005, p. 516).

Robinson (2005) takes the global view of hegemony one step further, questioning the nation state focus in neo-Gramscian theory altogether. He points rather to a "view of hegemony as a form of social 
domination exercised not by states but by social groups and classes operating through states and other institutions" (Robinson, 2005, p. 561). This is a more radical vision of not national and transnational class, or the expansion of a national class interests transnationally, regionally, or globally. This is rather a focus on class in itself as the primary unit of analysis regardless of national or international constrictions. Furthermore, "transnational or global approaches focus on how the system of nation-states and national economies, etc., are becoming transcended by transnational social forces and institutions grounded in the global system rather than the interstate system..." (Robinson, 2005, p. 561). That is, it is better to reject the proposition that we are speaking of hegemony of a particular state, or class beholden to a particularistic understanding of space such as that of the nation-state. Robinson instead speaks of the hegemony of a particular social force and related means of production. Robinson calls us to "focus on the horizontal integration of classes and social forces, that then operate through webs of national and transnational institutions... transnational capitalists and allied dominant strata integrate horizontally, and in the process move 'up' cross-nationally" (Robinson, 2005, p. 562). Bieling and Steinhilber (2000) reference Cox in a similar vein, pointing out that international hegemony is not "merely an order among states. It is an order within a world economy with a dominant mode of production which penetrates into all countries... a complex of international social relationships which connect the social classes of the different countries" (Cox, quoted in Bieling and Steinhilber, 2000). This understanding of transnational hegemony based on consent and organized around a means of production, in our case with a particular neoliberal logic, can lead us to view the EU as a transnational hegemony that is then interwoven with different manifestations of that larger system in and in between the transnational and the national.

\section{The EU as a Hegemonic Project}

How then is the EU a hegemonic project? Hegemonic projects from a neo-Gramscian perspective are not only processes of social restructuring. Hegemonic projects are in fact processes of what Gramsci called transformisimo. This is explained by Bieling and Steinhilber as "social and economic reform 'from above' in order to co-opt large parts of the population by providing allegedly attractive solutions for pressing economic and social problems" (2000, p. 38). To be more specific, hegemony is active. This hegemony has been reinforced at the European level by a small group of economic and political elites (Bieling and Steinhilber, 2000, p. 39). Bieling and Steinhilber further elaborate that the conditioning framework of European integration thus set up is based upon two primary logics that are based on neoliberalism. These are namely, competitive deregulation and competitive austerity (Bieling and Steinhilber, 2000, p. 39). This deregulation is then based on the idea of the common market and the flexibility of goods, services, capital, and this austerity is based on the idea of market discipline by which central banks are obliged to follow certain monetarist policies determined by the EMS and EMU.

The key arguments put in favor of the EMS, as well as the single market and the majority of EU developments revolve around the idea of projecting economic success as a means to secure the general good of the EU. This economic success is then targeted and legitimated based on logics inherent to a neoliberal perspective. Bieling and Steinhilber explain, "the key topic of the national and European discourse of modernization was 'competitiveness' which meant in the end a strategic priority to economic integration by means of deregulating national markets. An expression of these four efforts were the famous four liberties, i.e. of capital, commodities, services and workforce, as they are written down in the Single European Act" (2000, p. 42). This was a top-down regulation, that worked well when the economy was in a boom time, but tended to face crisis in times of economic downturn. This is because of the nature of the Single Market being top-down, which was not legitimized by active consensus, but "by the 'good performance of the task'... legitimized by 
success... and not by democratic debate or even approval..." (2000, p. 43). Again, this tended to work as long as times were good and brought about advantages, but opened wide with general public feelings of distrust and a lack of popular sovereignty if the situation was otherwise. Over time this arrangement has developed into "the belief that the EU membership is unalterable. The free movement of labor and capital are part of the process of globalization, the most recent transformative phase in capitalist growth, and similarly produces a 'logic of no alternative'..." (Gibbins, 2020, p. 7). Bieling and Steinhilber (2000) point out that while most of the EU discourse becomes more neoliberalized, large numbers of people, largely from the working class are becoming less and less willing to accept the consequences of neoliberalism and related restructuring (p. 45).

\section{The British "Race to the Bottom"}

At the same time of neoliberalization at the EU level, there has been a similar phenomenon at the UK level. Jessop (2018) observes measures in the UK from 1979 on, reinforcing "the ongoing pattern of de-industrialization and, where core industries survived, contributed to their balkanization" ( $p$. 1735). He further argues that, "without the economic, political, and social bases for a concerted national economic strategy, Britain's economic fortunes came to depend heavily on the vagaries of finance-dominated accumulation and the wider world market" (Jessop, 2018, p. 1735). These very economic policies have largely benefitted the city of London, and "rentier and producer service interest" that exist in London and the South-East as well as "mobile transnational capital" (Jessop, 2018, p. 1735). Rosamond (2019) similarly observes that Brexit has been a manifestation of larger British political cleavages connected to the neoliberal growth model based on the privatization of Keynesianism and opening the economy of the UK to foreign capital. The central crisis of this growth model was that it only worked when there was increased exposure to UK property owners of international markets, and therefore when the US sub-prime mortgage market crash happened in 2007-2008, both the machinery of this particular system collapsed as well as its support base (Rosamond 2019, p. 411). The Labour Party governments, calling themselves "New Labour" post 1997, became associated with the construction of a "privatized Keynesianism" "and the rolling out of asset-based welfare in the UK" (Rosamond, 2019, p. 411). This Labour policy, came to be seen as "irresponsible over-spending that had produced recurrent budget deficits and unsustainable levels of accumulated public debt" (Rosamond, 2019, p. 411). This means that there was a crisis throwing the hegemonic project into disarray, and then government response to the crisis was done in a way that garnered discontent. Rosamond observes that this culminated in Brexit as "a form of societal backlash that was originally hatched in the underperformance/collapse of the UK's most recent growth model" (Rosamond, 2019, p. 412).

This backlash is understandable if we contextualize it in the politics of support of the EU project. The UK growth model has been undertaken in the context of EU membership and liberalization. Rosamond explains, “...the terms under which the UK entered the European Communities in 1973 combines with the liberalizing thrust of European economic integration from the mid-1980s meant that the British state's 'City-first' statecraft was not only reconcilable with EU membership, but was also likely to augment the City's position as the key international financial center" (Rosamond, 2019, p. 412). This is because it stands to be the most benefitted by the opening up of international financial markets. It is also true that although the neoliberal growth model relied on the exposure of UK citizens to global finance it was also based upon a system that generated regional and socio-economic inequalities (Rosamond, 2019, p. 412).

Jessop (2018) also points out that economic shifts have been at the expense of "regions and thirdtier cities and towns" in the north and south of the UK where industry has been eroded and manufacturing has experienced losses since the expansion of neoliberalism. In a sense, Jessop 
describes uneven development and the regional polarization of wealth. He states, "neoliberalization has promoted the deeper integration of (parts of) British economic space into the circuits of international financial capital and advantaged international profit-producing capital" (Jessop, 2018, p. 1736). Rosamond also points to an "economic geography" for the UK, manifested in Brexit voting. In summary he observes a correlation between pro-Brexit voting and areas "most negatively affected by economic globalization" (namely, the north, the midlands, and the east) with London, a region with 45.1 percent of the UK's financial output, giving a remain vote of approximately 60 percent (Rosamond, 2019, p. 413). The conclusion for Rosamond (2019) as well as Jessop (2017 and 2018) is that the referendum represents at least in part a revolt against the financialized neoliberal economic model in the UK and, by extension, its embeddedness in the EU.

\section{The Shifting Views of the Labour Party}

For many in the UK, including those in the Labour Party, especially in the 70s, the EEC (predecessor of the EU) was originally seen as a "capitalist club." Gibbins references numerous voices from British politics of the 70s on the topic of further European integration into the EEC, calling it a "club of relatively privileged nations which want to maintain their positions," "the largest capitalist club in the world," and "the treaty of Rome as a Magna Carta for the barons of multinational megacorporations" (quoted in Gibbins, 2020, p. 6). Tony Benn, a member of the Labour Party, summed up the common view of his party in the 70s in a cabinet meeting from 1975, stating that "in practice, Britain will be governed by a European coalition government that we cannot change, dedicated to a capitalist or market oriented theology" (quoted in Salter, 2018, p. 470). What is more, two months prior to the 1975 referendum, the Labour party voted against membership in the European Communities and 39 of 46 associated labor unions rejected the idea (Salter, 2018, p. 470). Often this past of the Labour party in rejecting further European integration is forgotten. The message of the majority of the Labour Party of the 70s was clear: we should not join a transnational neoliberalist club in Europe.

Gill observes that the left-wing alternative has been assimilated and disarmed by the larger logic of neoliberalism (the hegemonic project). He argues that the current manifestations of socialism in the EU (his article was published in 2000), seem "to have been not the replacement of capitalism, but the civilizing of the capitalist mode of production, in effect conferring it with a hegemonic aura... institutional innovations... have been connected to the stabilization and legitimation of capitalism through the use of an expanding sphere of state regulation" (Gill, 2000, p. 18). He also points out that although the leftist alternative in Europe has been largely assimilated, "this is not to say that alternatives to the dominant political orthodoxy do not exist, especially on the right" (Gill, 2000, p. 18). Ironically, the biggest blow to challenging the hegemonic project lies in the politics of the left of center. When Delors added a social dimension to Europe at the Trades Union Congress of 1988, a significant impact was made in "converting core Labour Party supporters and policy influencers to pro-Europeanism" (Gibbins, 2020, p. 6). Thereby, the alternative was disarmed, and the debate no longer was one of neoliberalism versus social solidarity in British politics but one of British neoliberalism versus European neoliberalism. This promotion for some social protection helped ironically to hegemonize the EU as a (neo)liberalizing project. In a moment Delors had moved the European project "from being perceived as an exclusive bourgeoise project aiding the interests of capital... into a champion of workers' rights" (Gibbins, 2020, p. 7). 


\section{The Lack of an Outlet}

Fundamental social change only becomes possible in what is called "organic crisis" in a neoGramscian vocabulary, which is when the system faces structural (objective) and legitimation (hegemony/subjective) crises (Robinson, 2005, p. 572). In the 1990s and, arguably, into the 2000s there existed the dual problematics of structural crisis and social polarization leading up to an "organic crisis" in 2016. Robinson (2005) takes a look at how counter-hegemonic resistance has been manifested in his work. He observes that "the far right has been able to capitalize... on the insecurities of working and middle classes in the face of rapidly changing circumstances to mobilize a reactionary bloc" drawing "in particular on the insecurities of those sectors formerly privileged within national social structures of accumulation" that are now threatened by globalization (Robinson, 2005, p. 571). Zizek (2016) observes something similar in "the rise of rightwing nationalist populism in western Europe, which is now the strongest political force advocating the protection of working class interests, and simultaneously the strongest political force able to give rise to proper political passions." What is more concerning for Zizek in the case of Brexit is the lack of a viable internationalist alternative on the left in that the internationalist thrust has been reincorporated into the neoliberal project, whereas alternatives have been absorbed into nationalism on both left and right. This presents for Zizek (2016) a problematic situation in which the only alternatives to the neoliberal project lie in the "rediscovery of nationalism."

Jessop (2018, p. 1736) observes the weakened ties between the power bloc and the working class arising from decline in areas that lack the capacity to challenge the hegemony of neoliberalism, namely "heavy industry, retail capital, and small and medium enterprises." He makes the point that, "the recent legitimacy crisis results from the failure of successive neoliberal projects, pursued under Conservative, New Labour, and coalition governments alike, to deliver sustainable nationwide prosperity. The representational crisis is evident in a growing disconnection between the natural governing parties in Westminster, party members, and their voters" (Jessop, 2018, p. 1736). This results in the disaffection of the Brexit vote and opens the door for populism on both the right and the left. He concludes, "the legitimacy and representational crises were exacerbated by the loss of control over public opinion... over continued EU membership... there is a wider organic crisis in the social order" (Jessop, 2018, p. 1736-1737). This organic crisis revealed itself in debates over national and regional identities, North-South differences, splits between the intelligentsia and the common people, and splits between age groups among others.

The reality, as previously stated, is that the referendum was never only about membership in the EU for the majority of those who voted on it. Many of those who were voting saw rather the choice between neoliberalism or not (Jessop, 2017, p. 137). Regardless of this perception, "a choice for entry or exit would not affect the overall dominance of neoliberalism-only its specific form and mediations. A remain vote would have consolidated an authoritarian neoliberal Conservative regime committed to enduring austerity..." (Jessop, 2017, p. 137). Jessop however points out that the crisis symptoms were not rooted in the EU as it is, but rather in its form. He explains, "they were rooted in its neoliberal form, the crises of the Eurozone crisis-management, and the long-run failure to address crucial domestic issues that undermined economic and extra-economic competitiveness" (Jessop, 2017, p. 138). What is more concerning is that following the rejection of hegemony in the form of the Brexit vote, reincorporation immediately followed. Gramsci observed that, "the traditional ruling class, which has numerous trained cadres, changes men and programs and, with greater speed than is achieved by the subordinate classes, reabsorbs the control that was slipping from its grasp. Perhaps it may make sacrifices... but it retains power, reinforces it for the time being and uses it to crush its adversary" (1971, quoted in Jessop, 2017, p. 138). In the case of the Brexit vote, there has been a 
likewise recovery of the power bloc to re-establish hegemony into a kind of British neoliberal hegemony in the place of the previous more EU-oriented one.

\section{General Disconnect}

Andreouli and Nicholson (2018) interviewed focus groups of UK citizens on the topic of Brexit in the months preceding the Brexit vote. They cite that the leave vote found support particularly among "more disadvantaged working classes and the less educated, older and 'whiter' voters..." (Goodwin and Heath, 2016; Swales, 2016 quoted in Andreouli and Nicholson, 2018, p. 2). They further explain that this view suggests that leave voters were the "so-called 'left behind', or 'losers of globalization', who have been particularly hit by the effects of the 2008 financial crisis and by subsequent austerity policies" (Andreouli and Nicholson, 2018, p. 2). Swales (2016) further found that there was no significant difference between "left-wing" and "right-wing" orientation among leave voters (cited in Andreouli and Nicholson, 2018, p. 2). We can look at their focus groups for more insight as to the reasoning voters had underlying their choices.

The first observation made by Andreouli and Nicholson was that their participants saw politicians as generally untrustworthy regardless of the political orientation of the respondent. Those intending to vote leave "expressed mistrust towards politicians making specific reference to austerity policies and National Health Service (NHS) cuts, but also more generally, by arguing against what they saw as a corrupt political establishment" (Andreouli and Nicholson, 2000, p. 19).

One female leave voter explained:

I'm just so annoyed with the politicians. And specifically, this campaign to stay in, and just the stuff that they say. I think do you think we're stupid?... if they came and said, 'right so we're in the EU and this is what the EU is put into our country this year or in general'... why don't they do that? Why, if they've got all these facts and figures, why aren't they?... I think well if you're not telling me and all you're trying to do is just scaremonger continually, then I don't trust you. (Andreouli and Nicholson, 2018, p. 19)

Overall a certain "anti-politics" was observed among the leave voters, with many being outright antagonistic to the current political system as a whole. This was paired with a general sense that politicians were trying to manipulate voters into remaining. However, although this was stronger among the leave voters, remain and undecided voters professed a distrust of the political establishment as well, often explaining their choice as an act of pragmatism rather than real support.

Andreouli and Nicholson also observed that many of the participants made a separation between the economy as being a place of common sense and reason, and politics being a place of bias and manipulation. While many remain voters explained their choice as an act of economic pragmatism, making some kind of cost-benefit analysis, many leave voters explained their choice as an act of rebellion from globalist economic control.

One male undecided voter explained:

The way I feel the media has portrayed it along the lines of, if you are intelligent and sophisticated you will vote remain; if you're a bit stupid and uneducated you'll vote to leave... One media listed all these people. Look at these brilliant academics. We've got this banker, this investment banker, we've got this politician... (Andreouli and Nicholson, 2018, p. 23)

The importance of class difference in the psychology of the debate is clearly represented in this quotation. All of the major parties in the UK other than the UK Independence Party predominantly supported staying in the EU (Andreouli and Nicholson, 2000, p. 2). This was observed by many as having the "appropriate" result being dictated to them by a ruling class that had already become suspect due to widespread economic crisis. A general dissatisfaction, distrust of the authorities, and concern about the economy, underlined the justifications of voters of all three groups (leave, remain, and undecided).

Salter (2018) observes an overwhelming division between intellectuals and the larger society as roughly 9 percent of academics supported Brexit compared to a 52 percent of general population ( $p$. 
468). He also observes that "in common with all the major national and international institutions of government, industry, finance and the media, universities had campaigned vigorously for remaining in the EU. Rarely can European elites have been so unified on a single issue and rarely can university intellectuals have been so uncritical of the unquestioning adherence by such elites to the status quo" (Salter, 2018, p. 468). It seems that academics played their part in concert with the elite in promoting the existing neoliberal hegemony in the form of the current EU arrangement. We can here use the Gramscian idea of intellectuals playing a central role in the promotion or curtailing of hegemony. This is somewhat related to the position intellectuals have independent of class interests, in that they have an established position by virtue of their degree or supposed expertise. Salter explains, "if successfully recruited by a particular hegemony, this notional independence enables traditional intellectuals to act as 'experts in legitimation' of its power" (Salter, 2018, p. 468). They are then tasked with "the function of developing and sustaining the mental images, technologies and organizations which bind together the members of a class and of a historic bloc into a common identity" (Cox, 1983 quoted in Salter, 2018 , p. 468). This is, in the EU situation, a transnational historic bloc tied to a particular transnational order supporting the global pressure for a more integrated neoliberal Europe.

It is ironic that leftist parties, as well as left leaning intellectuals did not address the problematic fact that, "all the major investment banks and transnational corporations, the International Monetary Fund (IMF), the World Bank, the OECD, the CBJ, the Bank of England, Lloyds and the European Round Table of industrialists... unanimously supported remain" (Salter, 2018, p. 471). The same party that had voted two to one against joining a European organization described as a capitalist club in the 70s, declared support for remaining in it 218 to 10 in 2016 (Salter, 2018, p. 471). This shows the astonishing power of the hegemonic project to incorporate the intellectual class. And in such a situation in which voters are presented with all the mainstream parties supporting the neoliberal project, what are they to do? In what direction should the counter-hegemonic backlash turn? Salter (2018) poses another interesting question along the same line of thought, "why British academics who... are predominately on the left of the political spectrum, were prepared to give their support and legitimation to an EU project with an explicit neoliberal agenda, achieved through established elite networks, serviced by a centralized and unaccountable technocracy and largely disdainful of democracy" (p. 469-470). This brings us back to the idea of transformismo or the strategy by which potentially dangerous parts of the population are assimilated into the system of legitimation. This assimilation was largely part and parcel of the idea of social Europe as promoted by Delors and explained by Gibbins (2020) and Gill (2000) among others. The common people of the UK were then left with a desire for counter-hegemony and a situation of organic crisis, but nowhere to channel their general disillusionment. Brexit offered a chance for these people to finally voice their discontent, but proved ephemeral without the possibility of a substantial alternative, the leadership of the intellectual class, or a viable outlet.

\section{Conclusion}

In the end we have a phenomenon in which the people of the UK are put into a situation in which their economy has been hollowed out by transnational neoliberalist forces. In such a situation, the EU is seen as a far away, organ of the ruling class, and an organ without the consent of the public of the UK. Organic crisis has torn apart the legitimation of the hegemonic project, and called political legitimacy into question. When asked to respond to the British public on the Brexit result from the perspective of an intellectual from the EU, Slavoj Zizek stated, "Europe is now caught in a vicious cycle, oscillating between the false opposites of surrender to global capitalism and surrender to antiimmigrant populism - which politics has a chance of enabling us to step out of this mad dance?" (Zizek, 2016). The choice in the UK to vote for Brexit can be seen as a vehicle for the working class to 
voice their desire for a counter-hegemonic push, regardless of the repercussions of that vote in reality. This is because of a widespread lack of a significant challenge remaining among the left, as the majority of the leftist political establishment has been incorporated into the larger European neoliberal project. In such a situation the only outlet left for the working class to manifest its frustration lies in the populist right-wing that largely supported Brexit in the referendum. I posit in this paper that this support is not representative of a larger far right thrust in the political consciousness of the working class in the UK, but rather part of this larger rejection to the neoliberal system itself, as well as the establishment that is seen to represent it. After years of being "told what to do" by the political establishment and facing a technocratic EU without significant consensus mechanisms for the majority of the population, and finally being presented with a way to voice their disapproval (the Brexit vote) the working class has now voiced their larger desire for counter-hegemony. However, this push was quickly reabsorbed by the neoliberal establishment in the UK, and the revolutionary potential was thereby neutralized. In other words, one neoliberalism has been replaced with another.

\section{Disclosure Statement}

The author has declared no potential conflicts of interest with respect to the research, authorship, and/or publication of this article. The author has received no financial support for the research, authorship, and/or publication of this article.

\section{Notes on Contributor}

Allan Cooper Dell is a teaching assistant in the School of Foreign Languages at Ankara University, and a Ph.D. candidate in Area Studies at Middle East Technical University. He received his BA from Appalachian State University in Global Studies, and his MA from the German-Turkish Master's program in Social Sciences at the Humboldt University of Berlin and Middle East Technical University. His interests include: the sociology of space/urban sociology, border studies, migration, and the intersection of MENA and Europe.

\section{ORCID}

\section{Allan Cooper Dell iD https://orcid.org/0000-0001-8000-0809}

\section{Bibliography}

Andreouli, Eleni, and Cathy Nicholson (2018). Brexit and Everyday Politics: An Analysis of Focus Group Data on the EU Referendum. Political Psychology, 39 (6), 1323-1338.

Bieler, Andreas (2005). Class Struggle over the EU Model of Capitalism: Neo-Gramscian Perspectives and the Analysis of European Integration. Critical review of International Social and Political Philosophy, 8 (4), 513-526.

Bieler, Andreas, and Adam David Morton (2004). A Critical Theory Route to Hegemony, World Order and Historical Change: neo-Gramscian perspectives in International Relations. Capital and Class, 28 (1), 85-113.

Bieling, Hans-Jürgen and Jochen Steinhilber (2000). Hegemonic Projects in the Process of European Integration. In HansJürgen Bieling and Jochen Steinhilber (Eds.), Dimensions of a Critical Theory of European Integration (pp. 33-57). Forschungsgruppe Europäische Gemeinschaften.

Gibbins, Justin (2020). Theorizing Brexit. UK/EU Relations and International Relations Theory. International Virtual Conference on Social Sciences.

Gill, Stephen (2000). Theoretical Foundations of a Neo-Gramscian Analysis of European Integration. In Hans-Jürgen Bieling and Jochen Steinhilber (Eds.), Dimensions of a Critical Theory of European Integration (pp. 15-32).

Forschungsgruppe Europäische Gemeinschaften.

Jessop, Bob (2017). The Organic Crisis of the British State: Putting Brexit in its Place. Globalizations, 14 (1), 133-141. 


\section{Dell}

Jessop, Bob (2018). Neoliberalization, Uneven Development, and Brexit: Further Reflections on the Organic Crisis of the British State and Society. European Planning Studies, 26 (9), 1728-1746.

Morgan, Paul (2016). BBCNews Referendum the moment they knew 24/6/16 (Video file), https://www.youtube.com/watch?v=DVDH0nsJ0jA (24.06.2016).

Robinson, William (2005). Gramsci and Globalization: From Nation-State to Transnational Hegemony. Critical Review of International Social and Political Philosophy, 8 (4), 559-574.

Rosamond, Ben (2019). Brexit and the Politics of UK Growth Models. New Political Economy, 24 (3), 408-421.

Salter, Brian (2018). When Intellectuals Fail? Brexit and Hegemonic Challenge. Competition \& Change, 22(5), 467-487.

Žižek, Slavoj (2016). Dear Britain. (2016, June 4). The Guardian. https:/ /www.theguardian.com/books/2016/jun/04/dearbritain-letters-from-europe-referendum. 